\author{
Sh.Sh. Ibraev ${ }^{1,2}$, L.S. Kainbaeva ${ }^{1}$, S.K. Menlikhozhayeva ${ }^{1}$ \\ ${ }^{1}$ Korkyt Ata Kyzylorda State University, Kyzylorda, Kazakhstan; \\ ${ }^{1,2}$ Institute of Mathematics and Mathematical Modeling, Almaty, Kazakhstan \\ (E-mail: ibrayevsh@mail.ru)
}

\title{
Cohomology of simple modules for algebraic groups
}

In this paper, we consider questions related to the study of the cohomology of simple and simply connected algebraic groups with coefficients in simple modules. There are various calculating methods for them. One of the effective methods is to study the properties of the Lyndon-Hochschild-Serre spectral sequence with respect to the infinitesimal subgroup, the Frobenius kernel of a given algebraic group, and the properties of various cohomological sequences. We have studied the properties of various short exact and corresponding long exact cohomological sequences of modules over an algebraic group associated with simple modules with highest restricted weights. Some properties of the cohomology of the Frobenius kernel with coefficients in simple modules with higher restricted weights are described. We also studied the properties of the LyndonHochschild-Serre spectral sequence on the first quadrant for simple modules with highest restricted weights. The limiting values of the points of the first quadrant of the spectral sequence are described. It is proved that for the simple, simply connected algebraic group $G$ over an algebraically closed field $k$ of characteristic $p>h$ with an irreducible root system $R$ and for a simple $G$-module $V$ with restricted highest weight, there is an isomorphism of $G$-modules

$$
H^{j}(G, V) \cong \operatorname{Hom}_{G}\left(k, H^{j}\left(G^{1}, V\right)^{(-1)}\right) \text { for all } j \geq 0,
$$

where $G^{1}$ is the Frobenius map kernel for $G, h$ is the Coxeter number of the root system $R$. This isomorphism allows us to reduce the calculation of the cohomology of group $G$ with coefficients in simple modules with higher restricted weights to the calculation of the corresponding cohomology of the Frobenius kernel $G^{1}$.

Keywords: algebraic group, Chevalley group, representation of Lie group, Frobenius kernel, simple module, cohomology, spectral sequence, exact sequence, restricted weight.

\section{Introduction}

The cohomology of simple modules is known only for small degrees cohomology and for small groups. For example, the first degree cohomology of simple modules are completely calculated for $S L_{2}$ [1], $S L_{3}$ [2], $S p_{4}$ [3], $G_{2}, p \geq 13$ [4]. Similar results for the second cohomology of simple modules were obtained for the following groups: $S L_{2}$ [5], $S L_{3}$ [6], $S p_{4}, p>7$ [7], and $G_{2}, p \geq 7$ [8]. The third degree cohomology of simple modules is described for all simple algebraic groups of rank two [9].

In this paper, we continued the research which started in [10], [11]. We studied the cohomology of simple, simply connected algebraic groups with an irreducible root system over an algebraically closed field of positive characteristic with coefficients in simple modules with restricted highest weights. Let $G$ be a simple, simply connected algebraic group over an algebraically closed field $k$ of characteristic $p>0$ with an irreducible root system $R, \mathfrak{g}$ be a Lie algebra of the group $G$, and $G^{1}$ be the kernel of the Frobenius map $F_{G}: G \rightarrow G$. We will also apply the following standard notation:

$B$ is the Borel subgroup of $G$,

$T$ is the maximal torus of $G$,

$R_{+}$is the set of positive roots,

$S=\left\{\alpha_{1}, \cdots, \alpha_{l}\right\}$ is the set of simple roots,

$\lambda_{1}, \cdots, \lambda_{l}$ are the fundamental weights,

$X(T)$ is the additive character group of $T$,

$X_{+}(T)=\left\{\lambda \in X(T) \mid\left\langle\lambda, \alpha^{\vee}\right\rangle \geq 0\right.$ для всех $\left.\alpha \in S\right\}$ is the set of dominant weights,

$X_{1}(T)=\left\{\lambda \in X(T) \mid 0 \leq\left\langle\lambda, \alpha^{\vee}\right\rangle<p\right.$ для всех $\left.\alpha \in S\right\}$ is the set of restricted weights,

$s_{\alpha, r p} \cdot \lambda=\lambda-\left\langle\lambda+\rho, \alpha^{\vee}\right\rangle \alpha+r p \alpha, \alpha \in R_{+}, r \in \mathbb{Z}$ is the action of the affine Weyl group $W_{p}$ on $X(T)$,

$k_{\lambda}$ is the one-dimensional $B$-module, 
$H^{0}(\lambda)=\operatorname{Ind} d_{B}^{G}\left(k_{\lambda}\right)$ is the $G$-module induced from the one-dimensional representation $k_{\lambda}$ of the Borel subgroup,

$L(\lambda)$ is the simple $G$-module with the highest weight $\lambda \in X_{+}(T)$.

For a rational $G$-module $L$, denote by $L^{(d)}$ the Frobenius twist of degree $d$. Thens, there is a unique $d>0$ and a rational $G$-module $V$ such that $V^{(d)}=L$. Denote it by $L^{(-d)}$.

We say that $G$-module $L$ admits a good filtration (or $H^{0}$-filtration) if the filtration factors are isomorphic to the modules induced from the one-dimensional representations of the Borel subgroup of $G$. A rational module $L$ over an algebraic group $G$ is called acyclic (or G-acyclic) if $H^{j}(G, L)=0$ for all $j>0$. For a simple $G$-module $V$ with restricted highest weight, the following isomorphisms of $G$-modules were obtained before:

$$
H^{1}(G, V) \cong \operatorname{Hom}_{G}\left(k, H^{1}\left(G^{1}, V\right)^{(-1)}\right)(\text { see }[10,(2.4)])
$$

and

$$
H^{2}(G, V) \cong H_{o m}\left(k, H^{2}\left(G^{1}, V\right)^{(-1)}\right), p \geq 3 h-3, \quad(\text { see }[11,(3.2)]) .
$$

In this paper, it is proved that a similar isomorphism is also hold in the general case. The main result is as follows

Theorem 1. Let $G$ be the algebraic group with an irreducible root system over an algebraically closed field $k$ of characteristic $p>h$ and $V$ be a simple finite-dimensional $G$-module with restricted highest weight. Then

$$
H^{j}(G, V) \cong \operatorname{Hom}_{G}\left(k, H^{j}\left(G^{1}, V\right)^{(-1)}\right) \text { for all } j \geq 0 .
$$

To obtain the condition $p>h$ we use the following known facts:

- If $p>h$ and $\lambda=w \cdot 0+p \nu$ for some $\nu \in X_{+}(T)$ and $w \in W$, then

$$
H^{i}\left(G^{1}, H^{0}(\lambda)\right)^{(-1)} \cong H^{0}\left(S^{(i-l(w)) / 2}\left(\mathbf{u}^{*}\right) \otimes k_{\nu}\right),
$$

where $\mathfrak{u}$ is the maximal nilpotent subalgebra of the Lie algebra $\mathfrak{g}$ that corresponds to negative roots and $S\left(\mathfrak{u}^{*}\right)$ is the symmetric algebra of $\mathfrak{u}^{*}[12$, p. 478], [13].

To apply formula (1) to calculate $H^{i}\left(G^{1}, H^{0}(w \cdot 0+p \nu)\right)^{(-1)}$, we will use the following character formula [12; 501]:

$$
\chi\left(H^{0}\left(S^{(i-l(w)) / 2}\left(\mathbf{u}^{*}\right) \otimes k_{\nu}\right)\right)=\sum_{\mu \in X_{+}(T)} \sum_{w \in W}(-1)^{l(w)} P_{(i-l(w)) / 2}(w \cdot \mu-\nu) \chi(\mu),
$$

where $P_{(i-l(w)) / 2}(w \cdot \mu-\nu)$ is the dimension of $(w \cdot \mu-\nu)$-weight subspace of $S^{(i-l(w)) / 2}\left(\mathfrak{u}^{*}\right)$.

- It is well known that the cohomology groups $H^{m}\left(G^{1}, H^{0}(\lambda)\right)^{(-1)}\left(\lambda \in X_{1}(T)\right)$ as $G$-modules admit a good filtration [12, Lemma 4.5]. Recall that a more hard condition was used in [11], the completely reducibility of the $G$-module $H^{1}\left(G^{1}, V\right)^{(-1)}$.

- If $\lambda \in X_{+}(T)$ and $j>0$ then $H^{j}\left(G, H^{0}(\lambda)\right)=0$, that is, the induced module $H^{0}(\lambda)$ is $G$-acyclic [14, Corol. 3.4], [15, Lemma 2.1, (iii)], [16, II.4.13, (1)].

To prove Theorem 1, we will also use the properties of the Lyndon-Hochschild-Serre spectral sequence. For the short exact sequence of group schemes

$$
1 \rightarrow G^{1} \rightarrow G \rightarrow G / G^{1} \rightarrow 1
$$

and the $G$-module $V$, the following Lyndon-Hochschild-Serre spectral sequence holds [16, I.6.6.(3)]:

$$
E_{2}^{n m}=H^{n}\left(G / G^{1}, H^{m}\left(G^{1}, V\right)\right) \Rightarrow H^{n+m}(G, V) ;
$$

Let $V$ be a simple $G$-module with restricted highest weight. According to [17, Sec.1, p. 768],

$$
H^{n}\left(G / G^{1}, H^{m}\left(G^{1}, V\right)\right) \cong H^{n}\left(G, H^{m}\left(G^{1}, V\right)^{(-1)}\right) .
$$

Hence,

$$
E_{2}^{n m} \cong H^{n}\left(G, H^{m}\left(G^{1}, V\right)^{(-1)}\right) .
$$

If $E_{\infty}^{n m}$ is the stable value of the point $(n, m)$ of the spectral sequence (3) then for any $j \geq 0$,

$$
H^{j}(G, V)=\bigoplus_{n+m=j} E_{\infty}^{n m}
$$




\section{Properties of the Lyndon-Hochschild-Serre spectral sequence}

First, we prove the properties of the spectral sequence (3) necessary for the proof of Theorem 1.

Lemma 1. Let $p>h$ and $V$ be a simple $G$-module with highest weight $\lambda \in X_{1}(T)$. Then for all $m>0$ there is an exact sequence of $G$-modules

$$
0 \longrightarrow H^{m-1}\left(G^{1}, H^{0}(\lambda) / V\right)^{(-1)} \longrightarrow H^{m}\left(G^{1}, V\right)^{(-1)} \rightarrow H^{m}\left(G^{1}, H^{0}(\lambda)\right)^{(-1)} \longrightarrow 0 .
$$

Proof. A simple $G$-module $V$ is the socle of the induced module $H^{0}(\lambda)$, i.e. there is a short exact sequence

$$
0 \longrightarrow V \longrightarrow H^{0}(\lambda) \longrightarrow H^{0}(\lambda) / V \longrightarrow 0
$$

Consider the corresponding long cohomological exact sequence of $G^{1}$-cohomology

$$
\cdots \longrightarrow H^{m}\left(G^{1}, V\right)^{(-1)} \longrightarrow H^{m}\left(G^{1}, H^{0}(\lambda)\right)^{(-1)} \longrightarrow H^{m}\left(G^{1}, H^{0}(\lambda) / V\right)^{(-1)} \longrightarrow \cdots .
$$

We apply induction on $m$. According to [18, 4.9], formula (6) is true for $m=1$. If it is true for all $m \leq a-1$, then from the exactness of sequence (7) it follows that the sequence

$$
0 \longrightarrow H^{a-1}\left(G^{1}, H^{0}(\lambda) / V\right)^{(-1)} \longrightarrow H^{a}\left(G^{1}, V\right)^{(-1)} \longrightarrow H^{a}\left(G^{1}, H^{0}(\lambda)\right)^{(-1)} \longrightarrow \cdots
$$

is also exact. If $H^{a}\left(G^{1}, H^{0}(\lambda)\right)^{(-1)}=0$ then as it can be seen from (8), that the sequence (6) is exact for $m=a$. If

$$
H^{a}\left(G^{1}, H^{0}(\lambda)\right)^{(-1)} \neq 0
$$

then according to (1) and (2),

$$
H^{a+1}\left(G^{1}, H^{0}(\lambda)\right)^{(-1)}=0 .
$$

In this case, from the long exact sequence (8) it follows that the sequence

$$
\begin{aligned}
& 0 \longrightarrow H^{a-1}\left(G^{1}, H^{0}(\lambda) / V\right)^{(-1)} \longrightarrow H^{a}\left(G^{1}, V\right)^{(-1)} \longrightarrow \\
& \longrightarrow H^{a}\left(G^{1}, H^{0}(\lambda)\right)^{(-1)} \longrightarrow H^{a}\left(G^{1}, H^{0}(\lambda) / V\right)^{(-1)} \longrightarrow 0
\end{aligned}
$$

is exact.

We prove that $H^{a}\left(G^{1}, H^{0}(\lambda) / V\right)^{(-1)}=0$. Indeed, the highest weight $\mu$ of any composition factor $H^{0}(\lambda) / V$ in Jantzen filtration is strongly linked to $\lambda$ and $\mu \preceq \lambda[19$, p. 54]. Therefore,

$$
H^{a}\left(G^{1}, H^{0}(\lambda) / V\right)^{(-1)}=0 .
$$

Thus, the short sequence (6) is exact for any $m>0$.

Lemma 2. Let $p>h$ and $\lambda \in X_{1}(T)$. Then $H^{n}\left(G, H^{m}\left(G^{1}, H^{0}(\lambda)\right)^{(-1)}\right)=0$ for all $n>0$ и $m \geq 0$.

Proof. According to (1) and [12, Lemma 4.5], $G$-module $H^{m}\left(G^{1}, H^{0}(\lambda)\right)^{(-1)}$ admits good filtration for all $m \geq 0$. It is well known that non-trivial induced modules are $G$-acyclic [14, Corol. 3.4], [15, Lemma 2.1, (iii)], $[16$, II.4.13, (1)]. Therefore,

$$
H^{n}\left(G, H^{m}\left(G^{1}, H^{0}(\lambda)\right)^{(-1)}\right)=0
$$

for all $n>0$ and $m \geq 0$.

Proposition 1. Let $p>h$ and $V$ be a non-trivial simple $G$ module with the highest weight from the restricted region. Then $E_{2}^{n, m}=0$ for all $n>0$ and for all $m \geq 0$.

Proof. According to the formula (4), $E_{2}^{n, m}=H^{n}\left(G, H^{m}\left(G^{1}, V\right)^{(-1)}\right)$. Let us prove the statements of the lemma by induction $m$. Since $V$ is a nontrivial simple $G^{1}$-module with highest restricted weight, then $H^{0}\left(G^{1}, V\right)^{(-1)}=0$. Therefore, $E_{2}^{n, 0}=0$ for all $n>0$. Assume that $E_{2}^{n, s}=0$ for all $n>0$ and $s<m$, we prove triviality $E_{2}^{n, m}$ for all $n>0$. Consider a long cohomological sequence of $G$-cohomology that corresponds to a short exact sequence (6)

$$
\begin{gathered}
\cdots \longrightarrow H^{n}\left(G, H^{m-1}\left(G^{1}, H^{0}(\lambda) / V\right)^{(-1)}\right) \\
\longrightarrow H^{n}\left(G, H^{m}\left(G^{1}, V\right)^{(-1)}\right) \longrightarrow H^{n}\left(G, H^{m}\left(G^{1}, H^{0}(\lambda)\right)^{(-1)}\right) \longrightarrow \cdots
\end{gathered}
$$


According to Lemma $2, H^{n}\left(G, H^{m}\left(G^{1}, H^{0}(\lambda)\right)^{(-1)}\right)=0$ for all $n>0$. Then from the exactness of sequence (9) it follows that, for all $n>0$, there is an isomorphism

$$
H^{n}\left(G, H^{m}\left(G^{1}, V\right)^{(-1)}\right) \cong H^{n}\left(G, H^{m-1}\left(G^{1}, H^{0}(\lambda) / V\right)^{(-1)}\right) .
$$

Now we prove that $H^{n}\left(G, H^{m-1}\left(G^{1}, H^{0}(\lambda) / V\right)^{(-1)}\right)=0$. By the induction hypothesis,

$$
E_{2}^{n, s}=H^{n}\left(G, H^{s}\left(G^{1}, V\right)^{(-1)}\right) \cong H^{n}\left(G, H^{s-1}\left(G^{1}, H^{0}(\lambda) / V\right)^{(-1)}\right)=0
$$

for all $s<m$. This means that the socle of $G$-module $H^{0}(\lambda) / V$ has $G^{1}$-cohomology of all degrees up to the degree $m-2$, which direct summands have zero $G$-cohomology. Let $L(\mu) \subset \operatorname{soc}_{G} H^{0}(\lambda) / V$. Then, applying Lemma 1 for $V=L(\mu)$, we obtain the following exact sequence:

$$
\begin{gathered}
0 \longrightarrow H^{m-2}\left(G^{1}, H^{0}(\mu) / L(\mu)\right)^{(-1)} \longrightarrow \\
H^{m-1}\left(G^{1}, L(\mu)\right)^{(-1)} \longrightarrow H^{m-1}\left(G^{1}, H^{0}(\mu)\right)^{(-1)} \longrightarrow 0 .
\end{gathered}
$$

Let $H^{m-2}\left(G^{1}, H^{0}(\mu) / L(\mu)\right)^{(-1)}=0$, then

$$
H^{m-1}\left(G^{1}, L(\mu)\right)^{(-1)} \cong H^{m-1}\left(G^{1}, H^{0}(\mu)\right)^{(-1)},
$$

Hence $H^{m-1}\left(G^{1}, L(\mu)\right)^{(-1)}$, as $G$-module, admits a good filtration. Thus,

$$
H^{n}\left(G, H^{m-1}\left(G^{1}, L(\mu)\right)^{(-1)}\right)=0 .
$$

If $H^{m-2}\left(G^{1}, H^{0}(\mu) / L(\mu)\right)^{(-1)} \neq 0$ then by induction hypothesis,

$$
H^{n}\left(G, H^{m-2}\left(G^{1}, H^{0}(\mu) / L(\mu)\right)^{(-1)}\right)=0 \text { for all } L(\mu) \subset \operatorname{soc}_{G} H^{0}(\lambda) / V .
$$

Then, due to the exactness of the sequence (11),

$$
H^{n}\left(G, H^{m-1}\left(G^{1}, H^{0}(\lambda) / V\right)^{(-1)}\right) \cong \bigoplus_{L(\mu) \subset \operatorname{soc} G H^{0}(\lambda) / V} H^{n}\left(G, H^{m-1}\left(G^{1}, H^{0}(\mu)\right)^{(-1)}\right)=0 .
$$

Since for all $L(\mu) \subset \operatorname{soc}_{G} H^{0}(\lambda) / V, G$-module $H^{m-1}\left(G^{1}, H^{0}(\mu)\right)^{(-1)}$ admits a good filtration, then $H^{n}\left(G, H^{m-1}\left(G^{1}, H^{0}(\lambda) / V\right)^{(-1)}\right)=0$. Therefore, according to the formula $(10), H^{n}\left(G, H^{m}\left(G^{1}, V\right)^{(-1)}\right)=0$. Thus, it is proved that $E_{2}^{n, m}=H^{n}\left(G, H^{m}\left(G^{1}, H^{0}(\lambda) / V\right)^{(-1)}\right)=0$ for all $n>0$ and for all $m \geq 0$.

Lemma 3. Let $p>h$ and $V$ be a simple $G$-module with highest weight from the restricted region. Then $E_{2}^{0, j}=E_{\infty}^{0, j}$ and $H^{j}(G, V)=E_{2}^{0, j}$ for all $j \geq 0$.

Proof. According to the definition, $E_{i+1}^{n, m}$ is the cohomology of the sequence

$$
E_{i}^{n-i, m+i-1} \rightarrow E_{i}^{n, m} \rightarrow E_{i}^{n+i, m-i+1} .
$$

Then it is obvious that $E_{j+2}^{0, j}=E_{\infty}^{0, j}$. Thus, $E_{2}^{0, j}=E_{\infty}^{0, j}$, if

$$
E_{2}^{0, j}=E_{3}^{0, j}=\cdots=E_{j+2}^{0, j} .
$$

Let us prove the condition (12) by induction on $j$. For $j=0$, this is obvious. Let (12) holds for all $j<a$. Let us prove that it is true for $j=a$. Since, according the induction hypothesis, $E_{a+2}^{n, m}$ is the cohomology of sequence

$$
E_{2}^{n-a-1, m+a} \rightarrow E_{2}^{n, m} \rightarrow E_{2}^{n+a+1, m-a},
$$

then $E_{a+1}^{0, a}=E_{a+2}^{0, a}$, if

$$
E_{2}^{-a-1,2 a}=E_{2}^{a+1,0}=0 \text { whenever } E_{2}^{0, a} \neq 0 .
$$

Let $E_{2}^{0, a} \neq 0$. Thus, it is obvious that $E_{2}^{-a-1,2 a}=0$ and, according to the Proposition $1, E_{2}^{a+1,0}=0$. Therefore, the condition (12) is true for all non-negative $j$, and $E_{2}^{0, j}=E_{\infty}^{0, j}$ for all $j \geq 0$.

According to the Proposition $1, E_{2}^{n, m}=0$ for all $n>0$ and $m \geq 0$. If $j=n+m$, then $E_{2}^{j-m, m}=0$ for $0 \leq m<j-1$. Then $E_{\infty}^{j-m, m}=E_{2}^{j-m, m}=0$ for all $0 \leq m \leq j-1$. Thus, according to the formula (5), $H^{j}(G, V)=E_{\infty}^{0, j}=E_{2}^{0, j}$ for all $j \geq 0$. 


\section{Proof of Theorem 1}

According to Lemma $3, H^{j}(G, V)=E_{2}^{0, j}$ for all $j \geq 0$. Using the formula (4), we obtain

$$
E_{2}^{0, j} \cong H^{0}\left(G, H^{j}\left(G^{1}, V\right)^{(-1)}\right) \text {. }
$$

Since

$$
H^{0}\left(G, H^{j}\left(G^{1}, V\right)^{(-1)}\right) \cong \operatorname{Hom}_{G}\left(k, H^{j}\left(G^{1}, V\right)^{(-1)}\right)
$$

then $E_{2}^{0, j} \cong \operatorname{Hom}_{G}\left(k, H^{j}\left(G^{1}, V\right)^{(-1)}\right)$. Therefore,

$$
H^{j}(G, V) \cong \operatorname{Hom}_{G}\left(k, H^{j}\left(G^{1}, V\right)^{(-1)}\right) .
$$

The proof of Theorem 1 is complete.

\section{References}

1 Cline E. Ext $t^{1}$ for $S L_{2} /$ E. Cline // Communications in Algebra. - 1979. - Vol. 7. - P. $107-111$.

2 Yehia S.B. Extensions of simple modules for the universal Chevalley group and parabolic subgroup: PhD thesis / Samy el Badawy Yehia. - Warwik, 1982. - $121 \mathrm{p}$.

3 Ye J.Ch. Extensions of simple modules for the group $S p(4, K)$ / J.Ch.Ye // Journal of the London Mathematical Society. - 1990. - Vol. 2(41). - P. 51-62.

4 Liu J.Ch. Extensions of simple modules for the algebraic group of type $G_{2} /$ J.Ch. Liu, J.Ch. Ye // Communications in Algebra. - 1993. - Vol. 21(6). - P. 1909-1946.

5 Stewart D.I. The second cohomology of simple $S L_{2}$-modules / D.I. Stewart // Proceedings of American Mathematical Society. - 2010. - Vol. 138. - P. 427-434.

6 Stewart D.I. The second cohomology of simple $S L_{3}$-modules / D.I. Stewart // Communications in Algebra. 2012. - Vol. 40. - No. 12. - P. 4702-4716.

7 Ibraev S.S. The second cohomology groups of simple modules over $S p_{4}(k) /$ S.S. Ibraev // Communications in Algebra. - 2012. - Vol. 40. - No. 3. - P. 1122-1130.

8 Ibraev S.S. The second cohomology groups of simple modules for $G_{2} /$ S.S. Ibraev // Siberian Electronic Mathematical Reports. - 2011. - Vol. 8. - P. 381-396.

9 Джумадильдаев А.С. О третьих когомологиях алгебраических групп ранга 2 в положительной характеристике / А.С. Джумадильдаев, Ш.Ш. Ибраев // Математический сб. - 2014. - Т. 205. — № 3. - C. $40-82$.

10 Ибраев Ш.Ш. О первой когомологии алгебраической группы и ее алгебры Ли в положительной характеристике / Ш.Ш. Ибраев // Математические заметки. - 2014. - Т. 96. - № 4. - С. $512-521$.

11 Ибраев Ш.Ш. О второй когомологии алгебраической группы и ее алгебры Ли в положительной характеристике / Ш.Ш. Ибраев // Математические заметки. - 2017. - Т. 101. - № 5. - С. $723-732$.

12 Andersen H.H. Cohomology of induced representations for algebraic groups / H.H. Andersen, J.C. Jantzen // Mathematische Annalen. - 1984. - Vol. 269. - № 4. - P. 487-524.

13 Kumar S. Frobenius splitting of cotangent bundles of flag varieties / S.Kumar, N. Lauritzen, J. Thomsen // Inventiones Mathematicae. - 1999. - Vol. 136. - P. 603-621.

14 Cline E. Rational and generic cohomology / E. Cline, B. Parshal, L. Scott, W. van der Kallen // Inventiones Mathematicae. - 1977. - Vol. 39. - P. 143-163.

15 Friedlander E.M. Cohomology of Lie algebras and algebraic groups / E.M.Friedlander, B.J. Parshal // American Journal of Mathematics. - 1986. - Vol. 108. - P. 235-253.

16 Jantzen J.C. Representations of algebraic groups. Second edition: Mathematical Surveys and Monographs / J.C. Jantzen // American Mathematical Society, Providence. - 2003. - 107.

17 Sullivan J.B. Frobenius operations on Hochschild cohomology / J.B. Sullivan // American Journal of Mathematics. - 1980. - Vol. 102. - № 4 - P. 765-780.

18 Jantzen J.C. First cohomology groups for classical Lie algebras / J.C. Jantzen // Progress in Mathematics. - 1991. - Vol. 95. - P. 291-300. 
19 Andersen H.H. The strong linkage principle / H.H. Andersen // Journal fur die reine und angewandte Mathematik. - 1980. - Vol. 315. - P. 53-59.

\author{
Ш.Ш. Ыбыраев, Л.С. Каинбаева, С.Қ. Меңліқожаева
}

\title{
Алгебралық группалар үшін жәй модульдердің когомологиялары
}

Мақалада жәй бірбайланысқан алгебралық группалардың коэффициенттерінің жәй модульдердегі когомологияларын зерттеуге байланысты сұрақтар қарастырылған. Оларды есептеудің әртүрлі әдістері бар. Тиімді есептеу әдістердің бірі - бұл, инфинитезимальді ішкі группаға - берілген алгебралық группаның Фробениус ядросына қатысты Линдон-Хохшильд-Серр спектрлік тізбектерінің қасиеттерін және әртүрлі когомологиялық дәл тізбектердің қасиеттерін пайдалану. Авторлар үлкен салмағы шектелген жәй модульдерге қатысты алгебралық группа модульдерінің әртүрлі қысқа дәл және сәйкесті ұзын дәл когомологиялық тізбектердің қасиеттерін зерттеді. Фробениус ядросының коэффициенттері үлкен салмағы шектелген жәй модульдердегі когомологияларының кейбір қасиеттері сипатталды. Сонымен қатар, үлкен салмағы шектелген жәй модульдер үшін Линдон-ХохшильдСерр спектрлік тізбектерінің бірінші квадранттағы қасиеттері зерттелді. Спектрлік тізбектің бірінші квадранттағы нүктелерінің шектік мәндері есептелді. Сипаттамасы $p>h$ алгебралық тұйық $k$ өрісіне қатысты жәй бірбайланысқан, түбірлер жүйесі $R$ келтірілмеген $G$ алгебралық группасы және жоғары салмағы шектелген жәй $V G$-модулі үшін:

$$
H^{j}(G, V) \cong \operatorname{Hom}_{G}\left(k, H^{j}\left(G^{1}, V\right)^{(-1)}\right) \text { барлығы } j \geq 0,
$$

мұндағы $G^{1}-G$ үшін Фробениус бейнелеуінің ядросы, $h-R$ түбірлер жүйесінің Кокстер саны. Бұл изоморфизм $G$ группасының коэффициенттері жоғары салмағы шектелген жәй модульдердегі когомологияларын есептеуді $G^{1}$ Фробениус ядросының сәйкесті когомологияларын есептеуге әкеледі.

Kiлm сөздер: алгебралық группа, Шевалле группасы, Ли группасының көрінісі, Фробениус ядросы, жәй модуль, когомология, спектрлік тізбек, дәл тізбек, шектелген салмақ.

\section{Ш.Ш. Ибраев, Л.С. Каинбаева, С.К. Менликожаева \\ Когомологии простых модулей для алгебраических групп}

В статье рассмотрены вопросы, касающиеся изучения когомологии простых односвязных алгебраических групп с коэффициентами в простых модулях. Существуют различные методы их вычисления. Одним из эффективных методов является использование свойств спектральной последовательности Линдона-Хохшильда-Серра относительно инфинитезимальной подгруппы - ядра Фробениуса данной алгебраической группы и свойств различных точных когомологических последовательностей. Авторами изучены свойства различных коротких точных и соответствующих длинных точных когомологических последовательностей модулей над алгебраической группой, связанных с простыми модулями со старшими ограниченными весами. Описаны некоторые свойства когомологии ядра Фробениуса с коэффициентами в простых модулях со старшими ограниченными весами. Кроме того, исследованы свойства спектральной последовательности Линдона-Хохшильда-Серра на первом квадранте для простых модулей со старшими ограниченными весами. Описаны предельные значения точек первого квадранта спектральной последовательности. Доказано, что для простой односвязной алгебраической группы $G$ над алгебраически замкнутым полем $k$ характеристики $p>h$ с неприводимой системой корней $R$ и для простого $G$-модуля $V$ со старшим ограниченным весом имеет место изоморфизм $G$ модулей

$$
H^{j}(G, V) \cong \operatorname{Hom}_{G}\left(k, H^{j}\left(G^{1}, V\right)^{(-1)}\right) \text { для всех } j \geq 0,
$$

где $G^{1}$ - ядро отображения Фробениуса для $G ; h$ - число Кокстера системы $R$. Данный изоморфизм позволяет свести вычисление когомологии группы $G$ с коэффициентами в простых модулях с ограниченными старшими весами к вычислению соответствующих когомологии ядра Фробениуса $G^{1}$. 
Ключевые слова: алгебраическая группа, группа Шевалле, представление группы Ли, ядро Фробениуса, простой модуль, когомология, спектральная последовательность, точная последовательность, ограниченный вес.

\section{References}

1 Cline, E. (1979). Ext ${ }^{1}$ for $S L_{2}$. Communications in Algebra, 7, 107-111.

2 Yehia, S.B. (1982). Extensions of simple modules for the universal Chevalley group and parabolic subgroup. Ph.D. thesis. Warwik.

3 Ye, J.Ch. (1990). Extensions of simple modules for the group $S p(4, K)$. Journal of the London Mathematical Society, 2(41), 51-62.

$4 \mathrm{Liu}$, J.Ch. \& Ye, J.Ch. (1993). Extensions of simple modules for the algebraic group of type $G_{2}$. Communications in Algebra, 21(6), 1909-1946.

5 Stewart, D.I. (2010). The second cohomology of simple $S L_{2}$-modules. Proceedings of American Mathematical Society, 138, 427-434.

6 Stewart, D.I. (2012). The second cohomology of simple $S L_{3}$-modules. Communications in Algebra, 40 , 12, 4702-4716.

7 Ibraev, S.S. (2012). The second cohomology groups of simple modules over $S p_{4}(k)$. Communications in Algebra, V. 40, No 3, 1122-1130.

8 Ibraev, S.S. (2011). The second cohomology groups of simple modules for $G_{2}$. Siberian Electronic Mathematical Reports, 8, 381-396.

9 Dzhumadildaev, A.S. \& Ibraev, Sh.Sh. (2014). O tretikh kohomolohiiakh alhebraicheskikh hrupp ranha $2 \mathrm{v}$ polpzhitelnoi kharakteristike [On the third cohomology of algebraic groups of rank two in positive characteristic]. Matematicheskii sbornik - Sbornic: Mathematics, 205, No 3, 40-82 [in Russian].

10 Ibraev, Sh.Sh. (2014). O pervoi kohomoloii alhebraicheskoi hruppy i ee alhebry Li v polozhitelnoi kharakteristike [On the first cohomology of an algebraic group and its Lie algebra in positive characteristic]. Matematicheskie zametki - Mathematical notes, 96, No 4, 512-521 [in Russian].

11 Ibraev, Sh.Sh. (2017). O vtoroi kohomolohii alhebraicheskoi hruppy i ee alhebry Li v polozhitelnoi kharakteristike [On the Second Cohomology of an Algebraic Group and of Its Lie Algebra in a Positive Characteristic]. Matematicheskie zametki - Mathematical notes, 101, No 5, 723-732 [in Russian].

12 Andersen, H.H. \& Jantzen, J.C. (1984). Cohomology of induced representations for algebraic groups. Mathematische Annalen, 269, No 4, 487-524.

13 Kumar, S., Lauritzen, N. \& Thomsen, J. (1999). Frobenius splitting of cotangent bundles of flag varieties. Inventiones Mathematicae, 136, 603-621.

14 Cline, E., Parshal, B., Scott, L. \& van der Kallen, W. (1977). Rational and generic cohomology. Inventiones Mathematicae, 39, 143-163.

15 Friedlander, E.M., \& Parshal, B.J. (1986) Cohomology of Lie algebras and algebraic groups. American Journal of Mathematics, 108, 235-253.

16 Jantzen, J.C. (2003). Representations of algebraic groups. Second edition: Mathematical Surveys and Monographs. American Mathematical Society, Providence, $10 \%$.

17 Sullivan, J.B. (1980). Frobenius operations on Hochschild cohomology. American Journal of Mathematics, 102, No 4, P. 765-780.

18 Jantzen, J.C. (1991). First cohomology groups for classical Lie algebras. Progress in Mathematics, 95, 291-300.

19 Andersen, H.H. (1980). The strong linkage principle. Journal fur die reine und angewandte Mathematik, $315,53-59$. 